\title{
Pengaruh levels of inquiry-interactive demonstration terhadap kemampuan berpikir tingkat tinggi siswa kelas VIII SMP pada materi tekanan zat
}

\author{
Itsna Yunida Al Husna, Susilowati*, Erni Yulianti \\ Universitas Negeri Malang, Jl. Semarang No. 5 Malang, Jawa Timur, Indonesia \\ *Penulis korespondensi, Surel: susilowati.fmipa@um.ac.id
}

Paper received: 01-05-2021; revised: 15-05-2021; accepted: 31-05-2021

\begin{abstract}
Abstrak
Berdasarkan pengamatan pembelajaran IPA SMP di Malang masih melibatkan peran guru yang dominan. Siswa tidak memiliki pemahaman yang mendalam mengenai suatu materi karena tidak memiliki pengalaman secara langsung dalam proses mencari tahu. Hal ini menyebabkan kemampuan berpikir tingkat tinggi cenderung rendah. Oleh karena itu, diperlukan model pembelajaran yang mampu mengembangkan kemampuan berpikir tingkat tinggi siswa. Tujuan penelitian ini adalah untuk mengetahui pengaruh Levels of Inquiry-Interactive Demonstration dibandingkan dengan Levels of Inquiry-Discovery Learning terhadap kemampuan berpikir tingkat tinggi siswa kelas VIII SMP. Jenis penelitian ini adalah quasi experiment dengan teknik posttest only control group design. Kelas eksperimen menggunakan Levels of Inquiry-Interactive Demonstration dan kelas kontrol menggunakan Levels of Inquiry-Discovery Learning. Instrumen penelitian terdiri atas 20 soal pilihan ganda kemampuan berpikir tingkat tinggi yang valid dengan tingkat reliabilitas 0,872 . Analisis data menggunakan uji-t. Hasil penelitian menunjukkan kemampuan berpikir tingkat tinggi siswa yang belajar dengan Levels of Inquiry-Interactive Demonstration lebih tinggi dibandingkan Levels of Inquiry-Discovery Learning.
\end{abstract}

Kata kunci: Levels of Inquiry-Interactive Demonstration; kemampuan berpikir tingkat tinggi

\section{Pendahuluan}

Salah satu prinsip pembelajaran IPA berdasarkan Permendikbud No 22 Tahun 2016 adalah siswa dari yang diberitahu menjadi mencari tahu. Pembelajaran IPA menekankan pada pengalaman langsung untuk mengembangkan kompetensi agar siswa mampu memahami alam sekitar melalui proses mencari tahu dan berbuat. Keterampilan dalam mencari tahu dan berbuat tersebut disebut dengan keterampilan proses penyelidikan atau inquiry skills (Trianto, 2010: 152).

Berdasarkan hasil pengamatan pada SMP di Malang, pembelajaran IPA di SMP masih melibatkan peran guru yang dominan. Siswa tidak memiliki pemahaman yang mendalam mengenai suatu materi karena tidak memiliki pengalaman secara langsung dalam proses mencari tahu. Keadaan ini menyebabkan pengalaman belajar yang diperoleh siswa tidak utuh. Pengalaman belajar yang tidak utuh membuat siswa hanya mempelajari IPA pada domain kognitif yang terendah (Trianto, 2010: 154). Kondisi ini menyebabkan siswa dalam kegiatan belajar tidak terbiasa mengembangkan potensi berpikirnya. Potensi berpikir yang tidak berkembang menyebabkan kemampuan berpikir tingkat tinggi siswa cenderung lemah.

Kemampuan berpikir tingkat tinggi atau higher order thinking skills (HOTS) merupakan suatu kemampuan berpikir yang tidak hanya membutuhkan kemampuan mengingat saja. Kemampuan berpikir tingkat tinggi juga membutuhkan kemampuan lain yang lebih tinggi, seperti kemampuan analisis, evaluasi, dan mencipta. Kemampuan berpikir tingkat tinggi 
didefinisikan sebagai penggunaan pikiran secara lebih luas untuk menemukan tantangan baru (Heong, dkk, 2011).

Newman and Wehlage (1992) menyatakan bahwa dengan kemampuan berpikir tingkat tinggi siswa akan belajar lebih mendalam, memahami konsep lebih baik, mampu memecahkan masalah, mampu mengkonstruksi, berhipotesis, dan memahami hal-hal kompleks menjadi lebih jelas. Kemampuan berpikir tingkat tinggi merupakan aspek penting dalam proses pembelajaran. Ketika seseorang berpikir dapat mempengaruhi kemampuan dalam belajar, kecepatan dan keefektivan dari proses belajarnya. Oleh karena itu, kemampuan berpikir berhubungan dengan proses berpikir. Kemampuan berpikir tingkat tinggi penting bagi siswa dalam menyelesaikan permasalahan yang ditemukan selama proses belajar, sehingga dapat mengembangkan kemampuan siswa dalam bersaing, mengembangkan intelektual siswa, dan membantu siswa mengatasi ketidaksesuaian dalam proses belajar (Heong, dkk, 2011).

Menurut Thomas dan Thorne (2011) kemampuan berpikir tingkat tinggi dapat dipelajari dan diajarkan pada siswa. Oleh karena itu, guru sebagai pendidik harus menciptakan suatu pembelajaran yang membuat siswa menjadi aktif untuk mengolah kemampuan kognitifnya sehingga dapat mengasah kemampuan berpikir tingkat tinggi siswa. Salah satu cara untuk membuat siswa aktif dalam mengikuti pembelajaran, diperlukan model pembelajaran yang mendukung. Menurut Yuliati (2008: 5-6), pembelajaran IPA diarahkan untuk berinkuiri. Melalui pembelajaran inkuiri siswa dapat memperoleh pengalaman secara langsung dalam proses mencari tahu. Melalui proses mencari tahu tersebut akhirnya siswa dapat membangun konsep sendiri. Sehingga pengetahuan yang didapat atas temuan siswa sendiri.

Salah satu tingkatan pembelajaran inkuiri menurut Wenning adalah Levels of InquiryInteractive Demonstration. Levels of Inquiry-Interactive Demonstration merupakan sebuah model pembelajaran konstruktivistik yang berpusat pada siswa. Siswa diminta untuk memprediksi hasil eksperimen, mengamati, dan mendiskusikan prediksi yang telah dibuat (Zimrot \& Ashkenazi, 2007). Menurut Wenning (2005) levels of Inquiry-Interactive Demonstration mencakup demonstrasi guru, mengembangkan dan mengajukan pertanyaan penyelidikan. Menurut Ashkenazi dan Weaver (2007) melalui demonstrasi yang dilakukan guru dapat mengidentifikasi kemampuan awal siswa yang masih terbatas selanjutnya mengeksplorasi kemampuan siswa.

Berdasarkan latar belakang yang telah diuraikan, perlu dilakukan penelitian untuk mengetahui "Pengaruh Levels of Inquiry-Interactive Demonstration terhadap Kemampuan Berpikir Tingkat Tinggi Siswa Kelas VIII SMP pada Materi Tekanan Zat".

\section{Metode}

Metode penelitian ini adalah metode eksperimen semu. Bentuk penelitian yang digunakan adalah quasi experiment design dengan rancangan posttest only control group design. Adapun rancangan dalam penelitian ini dapat dilihat pada Tabel 1. 
Tabel 1. Rancangan Penelitian

\begin{tabular}{lll}
\hline Kelompok & Perlakuan & Posttest \\
\hline Eksperimen (E) & $\mathrm{X}_{1}$ & $\mathrm{O}_{1}$ \\
Kontrol (K) & $\mathrm{X}_{2}$ & $\mathrm{O}_{1}$ \\
\hline
\end{tabular}

(Creswell, 2012: 310)

Populasi dalam penelitian ini adalah seluruh siswa kelas VIII SMPN 1 Singosari. Pengambilan sampel dalam penelitian ini adalah dengan random sampling. Sampel dalam penelitian ini adalah kelas VIII B dan VIII C. Kelas VIII B sebagai kelas kontrol diberi perlakuan dengan model pembelajaran Levels of Inquiry-Discovery Learning dan kelas VIII C sebagai kelas eksperimen diberi perlakuan dengan model pembelajaran Levels of InquiryInteractive Demonstration.

Data yang dikumpulkan berupa data kuantitatif hasil nilai posttest siswa pada materi tekanan zat. Instrumen soal yang digunakan berupa 20 soal pilihan ganda kemampuan berpikir tingkat tinggi yang valid dan memiliki reliabilitas sebesar 0,872 dengan kriteria sangat tinggi.

Analisis data yang digunakan dalam penelitian ini adalah dengan uji-t. Analisis data menggunakan bantuan Microsoft Excel 2013. Analisis data diawali dengan uji prasyarat yakni uji normalitas dan uji homogenitas untuk menentukan jenis statistik yang digunakan. Uji normalitas dalam penelitian ini adalah menggunakan uji Kolmogorov Smirnov. Uji homogenitas dalam penelitian ini adalah menggunakan uji Levene.

\section{Hasil dan Pembahasan}

\subsection{Hasil Penelitian}

Data yang diperoleh dalam penelitian ini berupa data kemampuan awal siswa dan nilai posttest materi tekanan zat. Nilai kemampuan awal siswa diperoleh dari nilai ulangan pada materi sebelumnya yakni materi sistem pencernaan makanan. Untuk mengetahui kemampuan awal siswa, dilakukan uji beda yakni dengan uji-t. Uji beda diawali dengan uji prasyarat yakni normalitas dan homogenitas. Uji normalitas yang digunakan adalah uji Kolmogorov Smirnov. Tabel 2 berikut merupakan ringkasan uji normalitas kemampuan awal siswa.

Tabel 2. Hasil Uji Normalitas Kemampuan Awal Siswa

\begin{tabular}{|l|l|l|l|}
\hline Kelas Perlakuan & $\boldsymbol{D}_{\text {hitung }}$ & $\boldsymbol{D}_{\text {tabel }}$ & Kriteria \\
\hline Eksperimen & 0,239 & 0,248 & Normal \\
\hline Kontrol & 0,228 & 0,248 & Normal \\
\hline
\end{tabular}

Berdasarkan Tabel 2 diketahui bahwa pada kelas eksperimen nilai $D_{\text {hitung }}$ $(0,239)<D_{\text {tabel }}(0,248)$ dan pada kelas kontrol $D_{\text {hitung }}(0,228)<D_{\text {tabel }}(0,248)$. Hasil tersebut menunjukkan bahwa data pada kedua kelas terdistribusi secara normal. Selanjutnya dilakukan uji homogenitas menggunakan uji Levene. Tabel 3 berikut merupakan ringkasan uji homogenitas kemampuan awal siswa pada kedua kelas. 
Tabel 3. Hasil Uji Homogenitas Kemampuan Awal Siswa

\begin{tabular}{llll}
\hline Kelas Perlakuan & $\mathbf{F}_{\text {hitung }}$ & $\mathbf{F}_{\text {tabel }}$ & Kriteria \\
\hline $\begin{array}{l}\text { Ekperimen } \\
\text { Kontrol }\end{array}$ & 1,369 & 4,007 & Homogen \\
\hline
\end{tabular}

Berdasarkan Tabel 3 diketahui bahwa nilai $F_{\text {hitung }}(1,369)<F_{\text {tabel }}(4,007)$, sehingga dapat disimpulkan bahwa data kemampuan awal kedua kelas homogen. Setelah dilakukan uji prasyarat analisis, selanjutnya dilakukan uji kesamaan kemampuan awal siswa dengan uji-t two tiled. Tabel 4 berikut merupakan ringkasan uji-t kemampuan awal siswa.

Tabel 4. Hasil Uji-t Kemampuan Awal Siswa

\begin{tabular}{lccl}
\hline Kelas Perlakuan & $\mathbf{t}_{\text {hitung }}$ & $\mathbf{t}_{\text {tabel }}$ & Kesimpulan \\
\hline Eksperimen & & & $\begin{array}{l}\text { Tidak terdapat perbedaan } \\
\text { kemampuan awal siswa } \\
\text { pada kedua kelas }\end{array}$ \\
Kontrol & 1,170 & 2,002 & \\
\hline
\end{tabular}

Berdasarkan Tabel 4 diketahui bahwa $t_{\text {hitung }}(1,170)<t_{\text {tabel }}(2,002)$, artinya tidak ada perbedaan kemampuan awal diantara kelas eksperimen dan kontrol. Setelah diketahui bahwa kedua kelas memiliki kemampuan awal yang sama selanjutnya dilakukan uji hipotesis untuk menjawab rumusan masalah yang ditentukan. Pengujian hipotesis menggunakan uji-t one tiled untuk mengetahui model pembelajaran yang memiliki nilai kemampuan berpikir tinggi lebih tinggi.

Data kedua berupa nilai posttest siswa diperoleh setelah siswa mendapatkan perlakuan berupa pembelajaran dengan model Levels of Inquiry Interactive Demonstration pada kelas eksperimen dan model Levels of Inquiry-Discovery Learning pada kelas kontrol. Pemberian perlakuan pada masing-masing kelas dilakukan selama 5 kali pertemuan. Tabel 5 berikut merupakan ringkasan uji normalitas nilai posttest siswa setelah mendapat perlakuan.

Tabel 5. Uji Normalitas Nilai Posttest

\begin{tabular}{llll}
\hline Kelas perlakuan & $\boldsymbol{D}_{\text {hitung }}$ & $\boldsymbol{D}_{\text {tabel }}$ & Kriteria \\
\hline Eksperimen & 0,204 & 0,248 & Normal \\
Kontrol & 0,150 & 0,248 & Normal \\
\hline
\end{tabular}

Berdasarkan Tabel 5 diperoleh kemampuan berpikir tingkat tinggi untuk kelas eksperimen $D_{\text {hitung }}(0,204)<D_{\text {tabel }}(0,248)$, sedangkan untuk kelas kontrol diperoleh $D_{\text {hitung }}(0,150)<D_{\text {tabel }}(0,248)$. Berdasarkan hasil uji normalitas dapat disimpulkan kemampuan berpikir tingkat tinggi kedua kelas terdistribusi secara normal. Tabel 6 berikut merupakan ringkasan uji homogenitas nilai posttest siswa setelah mendapat perlakuan. 
Tabel 6. Uji Homogenitas Nilai Posttest

\begin{tabular}{llll}
\hline Kelas perlakuan & $\mathbf{F}_{\text {hitung }}$ & $\mathbf{F}_{\text {tabel }}$ & Kesimpulan \\
\hline $\begin{array}{l}\text { Eksperimen } \\
\text { Kontrol }\end{array}$ & 0,803 & 4,007 & Homogen \\
\hline
\end{tabular}

Berdasarkan Tabel 6 diperoleh $F_{\text {hitung }}(0,803)<F_{\text {tabel }}(4,007)$, sehingga kemampuan berpikir tingkat tinggi siswa pada kedua kelas homogen Selanjutnya dilakukan pengujian hipotesis untuk menentukan model pembelajaran yang memiliki nilai kemampuan berpikir tingkat tinggi yang lebih tinggi. Pengujian hipotesis menggunakan uji-t one tiled. Tabel 7 berikut merupakan ringkasan hasil uji-t .

Tabel 7. Hasil Uji-t Nilai Posttest

\begin{tabular}{lcll}
\hline Kelas Perlakuan & $\mathbf{t}_{\text {hitung }}$ & $\mathbf{t}_{\text {tabel }}$ & Kesimpulan \\
\hline Eksperimen & & & Kemampuan berpikir \\
& 3,058 & 1,671 & tingkat tinggi siswa pada \\
& & $\begin{array}{l}\text { kelas eksperimen lebih } \\
\text { tinggi dibandingkan }\end{array}$ \\
Kontrol & & \\
\hline
\end{tabular}

Berdasarkan Tabel 7 diketahui bahwa $t_{\text {hitung }}(3,058)>t_{\text {tabel }}(1,671)$, artinya kemampuan berpikir tingkat tinggi siswa yang belajar dengan model Levels of Inquiry-Interactive Demonstration lebih tinggi dibandingkan siswa yang belajar dengan model Levels of Inquiry-Discovery Learning.

\subsection{Pembahasan}

Berdasarkan analisis yang telah dilakukan, kemampuan berpikir tingkat tinggi siswa yang belajar dengan model Levels of Inquiry-Interactive Demonstration lebih tinggi dibandingkan dengan siswa Levels of Inquiry-Discovery Learning. Kedua model pembelajaran memiliki tahapan pembelajaran yang sama yakni observation, manipulation, generalization, verification, dan application. Namun, dalam proses pembelajaran terdapat perbedaan pada tahap manipulation, verification, dan application. Levels of Inquiry-Interactive Demonstration merupakan model pembelajaran konstruktivistik yang berpusat pada siswa. Tahapan pembelajaran dalam Levels of Inquiry-Interactive Demonstration membantu siswa dalam mengembangkan kemampuan berpikirnya. Tingkat kemampuan berpikir siswa semakin lebih baik jika keterlibatan guru semakin sedikit dan lebih banyak melibatkan siswa selama proses pembelajaran.

Pada tahap manipulation dalam pembelajaran Levels of Inquiry-Interactive Demonstration, siswa mengamati demonstrasi yang dilakukan guru kemudian menemukan suatu permasalahan berdasarkan demonstrasi tersebut. Proses siswa dalam menemukan permasalahan dapat melatih kemampuan berpikir tingkat tinggi siswa. Mainali (2012) dalam jurnalnya menyatakan bahwa kemampuan berpikir tingkat tinggi dapat berkembang ketika siswa menemukan suatu permasalahan baru.

Tahap verification dalam pembelajaran Levels of Inquiry-Interactive Demonstration, siswa mendapatkan penguatan materi dari demonstrasi ulang yang dilakukan oleh guru. Pada tahap ini, guru meluruskan semua persepsi sehingga siswa memiliki pemahaman yang sama. Guru mendemonstrasikan ulang dengan hasil yang 
jelas agar siswa membandingkan hasil demonstrasi dengan prediksi yang telah dibuat. Jika terdapat konsepsi alternatif dari siswa, guru harus menyelesaikannya dengan memberikan penguatan pada peserta didik (Wenning, 2012). Pemberian penguatan dilakukan dengan meluruskan konsepsi awal untuk memperbaiki pemahaman siswa.

Pada tahap application dalam pembelajaran Levels of Inquiry-Interactive Demonstration, siswa diberikan permasalahan baru. Pemberian permasalahan baru tersebut menuntut siswa untuk menggunakan pengetahuan yang telah diperolehnya untuk menganalisis dan menyelesaikan permasalahan tersebut. Kemampuan berpikir tingkat tinggi berkembang seiring siswa dihadapkan pada suatu permasalahan. Pemberian permasalahan oleh guru ketika siswa telah mendapatkan pemahaman yang jelas mengenai suatu konsep akan membantu membentuk pola berpikir siswa dan mengembangkan kemampuan berpikirnya. Siswa melibatkan kemampuan berpikir tingkat tingginya ketika mampu memisahkan informasi yang tidak berhubungan ke dalam suatu permasalahan (Mainali, 2012). Sehingga melalui proses tersebut kemampuan berpikir tingkat tinggi siswa dapat berkembang. Seperti yang disampaikan oleh Sofiah, Susanto dan Setiawani (2015) bahwa untuk mencapai kemampuan berpikir tingkat tinggi, siswa harus dibiasakan memecahkan permasalahan yang membutuhkan pemikiran untuk menganalisis, menilai, dan mencipta.

Kemampuan berpikir tingkat tinggi siswa yang menerima pembelajaran Levels of Inquiry-Discovery Learning lebih rendah dibandingkan dengan siswa yang menerima pembelajaran Levels of Inquiry Interactive Demonstration. Hal ini disebabkan siswa tidak memiliki pengalaman langsung dalam menemukan suatu permasalahan dan mengkonstruk pengetahuannya ke dalam permasalahan baru. Guru memiliki peran yang dominan selama pembelajaran sehingga proses berpikir siswa belum mencapai level yang tinggi. Kemampuan berpikir siswa lebih berkembang ketika siswa terlibat langsung dalam pengamatan, bertanya, merumuskan masalah, melakukan percobaan, dan evaluasi. Levels of InquiryInteractive Demonstration membantu siswa dalam mengembangkan kemampuan berpikir dengan keterlibatan siswa secara langsung dalam proses pembelajaran. Kemampuan berpikir siswa dalam mengkonstruksi materi yang dipelajari akan lebih mudah ketika siswa terlibat langsung dalam percobaan yang dilakukan dengan terarah dan terpola.

Hasil penelitian ini sejalan dengan penelitian yang dilakukan oleh Hidayati, Yuliati, dan Muhardjito (2015) yang menunjukkan bahwa melalui pembelajaran Levels of Inquiry-Interactive Demonstration kemampuan berpikir kritis siswa lebih tinggi dibandingkan dengan pembelajaran Levels of Inquiry-Discovery Learning selanjutnya penelitian Fibriati, Yuliati dan Yulianti (2016) menyatakan bahwa kemampuan pemecahan masalah siswa yang belajar dengan Levels of InquiryInteractive demonstration lebih tinggi dibandingkan Levels of Inquiry-Discovery Learning. Menurut Cohen (dalam Costa, 1985:44) kemampuan berpikir kritis dan kemampuan pemecahan masalah merupakan indikator kemampuan berpikir tingkat tinggi. 


\section{Simpulan}

\subsection{Kesimpulan}

Berdasarkan hasil analisis dan pembahasan, dapat disimpulkan bahwa penerapan Levels of Inquiry-Interactive demonstration dapat mengembangkan kemampuan berpikir tingkat tinggi siswa. Melalui pembelajaran Levels of Inquiry-Interactive demonstration, kemampuan berpikir tingkat tinggi siswa lebih tinggi dibandingkan pembelajaran Levels of Inquiry-Discovery Learning.

\subsection{Saran}

Levels of Inquiry-Interactive Demonstration dapat digunakan sebagai alternatif pembelajaran yang dapat mengembangkan kemampuan berpikir tingkat tinggi siswa.

\section{Daftar Rujukan}

Ashkenazi, G., \& Weaver, G. C. (2007). Using lecture demonstrations to promote the refinement of concepts: the case of teaching solvent miscibility. Chemistry Education Research and Practice, 8(2), 186-196.

Creswell, J. W. (2012). Educational research: planning. Conducting, and Evaluating.

Costa, A. L. (1985). Developing Minds: A resource bookfor teaching thinking. Association for Curriuclum and Supervision. Arlington, VA.

Fibriati, R. E., Yuliati, L., \& Yulianti, E. (2016). Kemampuan Pemecahan Masalah IPA Peserta Didik Kelas VII SMP yang Belajar dengan Model Levels of Inquiry-Interactive Demonstration. In Prosiding Seminar Nasional Pembelajaran IPA (pp. 33-37).

Heong, Y. M., Othman, W. B., Yunos, J. B. M., Kiong, T. T., Hassan, R. B., \& Mohamad, M. M. B. (2011). The level of marzano higher order thinking skills among technical education students. International Journal of Social Science and Humanity, 1(2), 121.

Hidayati, R. A. (2020). Pengaruh levels of inquiry-interactive demonstration terhadap kemampuan berpikir kritis siswa SMA pada mata pelajaran fisika kelas X. SKRIPSI Mahasiswa UM.

Mainali, B. P. (2012). Higher order thinking in education. Academic Voices: A Multidisciplinary Journal, 2, 5-10.

Newmann, F. M. (1992). Student engagement and achievement in American secondary schools. Teachers College Press, 1234 Amsterdam Avenue, New York, NY 10027 (paperback: ISBN-0-8077-3182-X, \$17.95; hardcover: ISBN-0-8077-3183-8, \$38)..

Sofiyah, S., \& Setiawani, S. (2015). Pengembangan Paket Tes Kemampuan Berpikir Tingkat Tinggi Matematika Berdasarkan Revisi Taksonomi Bloom Pada Siswa Kelas V SD. Artikel Ilmiah Mahasiswa Universitas Jember, 1.

Thomas, A., \& Thorne, G. (2009). How to increase higher order thinking. Metarie, LA: Center for Development and Learning.

Trianto, T. (2010). Model pembelajaran terpadu. Jakarta: Bumi Aksara.

Wenning, C. J. (2005). Levels of inquiry: Hierarchies of pedagogical practices and inquiry processes. In J. Phys. Teach. Educ. Online.

Wenning, C. J., \& Khan, M. A. (2011). Levels of Inquiry Model of Science Teaching: Learning sequences to lesson plans. Journal of Physics Teacher Education Online, 6(2), 17-20.

Yuliati, L. (2008). Model-model Pembelajaran Fisika: Teori dan Praktek. Malang: LP3 Universitas Negeri Malang.

Zimrot, R., \& Ashkenazi, G. (2007). Interactive lecture demonstrations: a tool for exploring and enhancing conceptual change. Chemistry Education Research and Practice, 8(2), 197-211. 